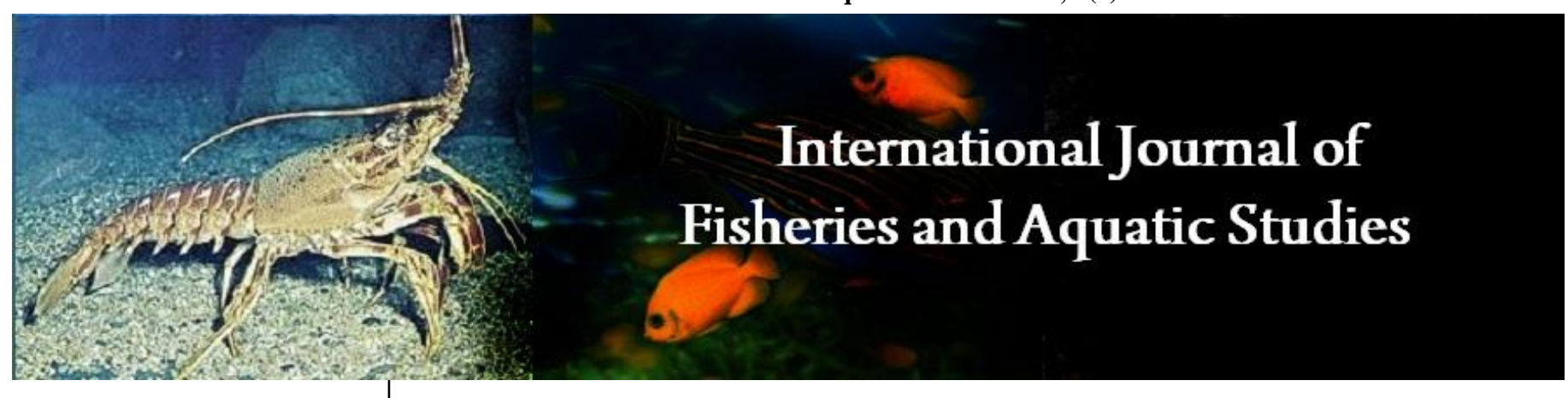

E-ISSN: 2347-5129

P-ISSN: 2394-0506

(ICV-Poland) Impact Value: 5.62

(GIF) Impact Factor: 0.549

IJFAS 2021; 9(2): 189-194

(C) 2021 IJFAS

www.fisheriesjournal.com

Received: 08-01-2021

Accepted: 12-02-2021

Shyam S Salim

ICAR-Central Marine Fisheries

Research Institute, Kochi,

Kerala, India

Sujitha Thomas

ICAR- Central Marine Fisheries

Research Institute, Kochi,

Kerala, India

Shinu AM

ICAR-Central Marine Fisheries Research Institute, Kochi,

Kerala, India
Corresponding Author:

Shyam S Salim

ICAR- Central Marine Fisheries

Research Institute, Kochi,

Kerala, India

\section{Assessing labour mobility in marine fishing operations in Karnataka}

\author{
Shyam S Salim, Sujitha Thomas and Shinu AM
}

DOI: $\underline{\text { https://doi.org/10.22271/fish.2021.v9.i2c.2450 }}$

\begin{abstract}
Mobility of labour across the country continues as a major source of labour supply in ensuring economic development across all sectors including the primary sector. The migrant labour in search of better employment emancipates better living conditions through meaningful employment and better financial status. The coastal states of Maharashtra with commendable marine fish landings provides states with commendable marine fish landings provide ample opportunities for migrant fishing labour across the year. The migrant labors are involved in harvest and post harvest operations. The present study tries to assess the major factors leading to labour migration and its effect in the state of Karnataka state. About 100 respondents were met for a primary survey and result reveals that the migration leads to the increase in savings. Majority (57 percent) of the respondents were youth (Below 30). Most respondents completed high school levels of education. The respondents migrated from 5 different states with majority from Jharkhand (36\%), Assam (23\%) and Orissa (13\%) to Mangalore district in Karnataka and the 54 percent respondents migrated in the year 2000. Garrett ranking method assessed the main reason and problems of migration and also used to find the effect of migration on socioeconomic status. The main reason for migration is the low income and the major difficulty during migration was the difficulty in language. The major achievement of the migrant labour had been the quality education provided to their children.
\end{abstract}

Keywords: migration, unemployment, garrett ranking, socioeconomic

\section{Introduction}

India is the fourth largest fishing nation in the world. Most people in the coastal region considered fishing as a main occupation. Marine fisheries sector provides several employment opportunities to the people. There is continuous increment in fish production in India. Karnataka is the state which has highest growth in fish production when comparing with the other coastal states in the country ${ }^{[1]}$. The Department of Fisheries was established in the year 1957 with an objective to give fillip for production of fish by utilizing the rich resources in marine and inland sector. Karnataka has about $320 \mathrm{~km}$ of coastline with $27,000 \mathrm{Sq} \cdot \mathrm{km}$ of continental shelf. The department is implementing several schemes for the better utilization of the resources and for the welfare of fishermen in particular and public in general.

The multiplicity and informality of functions and functionaries, means that the labour in the sector is also as diverse as the sector is, and so are the issues and challenges ${ }^{[2,3]}$. Fishers' livelihoods are characterized by a series of vulnerabilities and endemic poverty contributing to their migration decisions. However, fishers also migrate pro-actively to enhance their capacities and explore opportunities ${ }^{[4]}$. The most common reason for the migration is the employment opportunities and economic gains ${ }^{[5,6]}$. Migration is a very risky gamble for these migrant fishers with complexities involved in the recruitment process through local networks, the conditions of work and salaries, the unavoidable path to an irregular status sometimes migratory experience almost always leads to failure and increased poverty ${ }^{[7]}$. Migration has become a key facet of today's world. Migrants living outside their country of birth are 191 million ${ }^{[8,9]}$.

While livelihood strategies are diverse and multiple, for many poor people, migration represents a central component of these ${ }^{[10]}$. Migration has helped the migrant households avoid hunger, starvation, and death and it (migration) became a vital livelihood strategy, though it failed to evaluate the economic status of all migrating households. 
The housing pattern of the migrant fisher folk is better than the non-migrants ${ }^{[11]}$. Seasonal migration is an important and regular livelihood adaptation undertaken by many natural resource dependent communities in various parts of the world. The seasonal nature of fishing activities leaves marine fishers unemployed for parts of the year, which - combined with low earnings (that leave little surplus to survive lean periods) necessitates seeking alternative options during the lean season and migration is a response to this necessity ${ }^{[12]}$.

The migrant flow across the stats is determined by selected by the availability of opportunities and the period ${ }^{[13]}$. The poor economic condition tends the fishermen to migrate to another place. The problems of poverty and malnutrition faced in coastal areas can be simultaneously met through planned utilization of available local resources and encouraging participation of the local people in the fishing occupation ${ }^{[14]}$. There are several factors that lead to the migration such as personal factors and occupational factors. Personal matter includes size of the family. Large families need more money for living than small family. This will leads to the indebtedness. These also force the fishermen to migrate. The cause of flow of migrant fishermen into the fishing communities of Nigeria is due to her abundant fisheries resources. Possession of modern fishing inputs have enhanced their potential for migrating coupled with the network connection of old migrants and Baale (community leader) of the community of destination who give them temporary places to stay at a fee which is a stipulated portion of their fish catch. This confirms the assumptions of the neoclassical economic and networking theories ${ }^{[15]}$. The temporary migration is seven times larger than permanent migration, and is largely a rural phenomenon dominated by rural to urban migration. A regional pattern in temporary labour migration is evident in the low-income Central and North Indian states. Low economic, educational and social status significantly induces temporary labour migration in contrast to permanent labour migration ${ }^{[16]}$. As such, temporary labour migration appears to be a survival strategy of the rural poor in India ${ }^{[17]}$.

\section{Materials and Methods}

The study location was Mangalore fishing harbor in Dakshina Kannada District of coastal Karnataka. Karnataka with a coast line of $300 \mathrm{~km}$, has three coastal districts namely Dakshina Kannada, Udupi and Uttara Kannada has 96 landing centers including five major fishing Harbors. Among these Mangalore Fishing harbor is one of the biggest landing center contributing more than $30 \%$ of the marine fish landing in the state. Gears used for the fishing includes trawls (1715), seines (59), gillnets (1307) and hook and line (451). Trawls are the major contributor to the fishing. The trawlers are operating as single day and multiday trawlers with 9-14 days of fishing. Now combination vessels operated as trawler-cum-purse seiners, or trawler-cum- long liners, or gillnetter-cum-long liner during different season are operating from Mangalore Coast. All these vessels employ labourers from various states across the country. The data was collected from 100 migrants through personal interview using a well organized questionnaire.

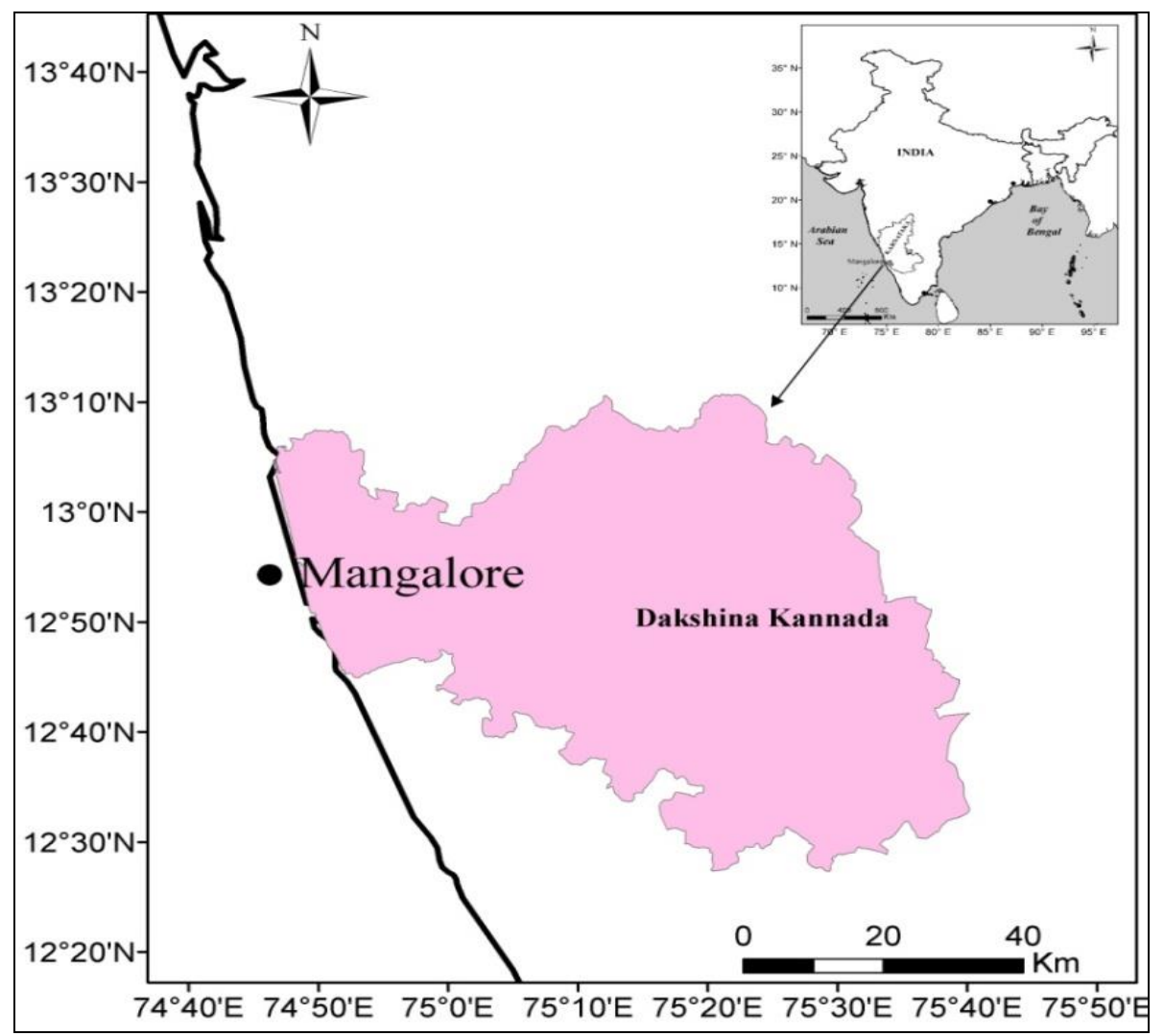

Fig 1: Locale of Study

The information related to demography, education status, average income, asset particulars, savings, indebtedness, expenditure pattern, details of migration, reasons for migration, problems during migration, and the major socio economic achievements through migration were elicited from the selected respondents. The Garrett's ranking technique is usually used to rank the preference indicated by the respondents on different factors. The Garette ranking technique is used to find the main reasons of migration and also the problems of migration. The ranks assigned by the 
respondents for different factors are converted into scores. The factors with highest mean value or Garrett score are considered to be the most important factor.

The Garette Ranking Technique was employed to rank the constraints. The order of merit given by the consumers was transmitted into scores. For converting the scores assigned by the exporter towards the particular problem, per cent position was worked out using the formula

$$
\text { Percent position }=100 \mathrm{X} \frac{\left(\mathrm{R}_{\mathrm{ij}}-0.5\right)}{\mathrm{N}_{\mathrm{j}}}
$$

Where,

$\mathrm{R}_{\mathrm{ij}}=$ Rank given for the $\mathrm{i}^{\text {th }}$ attribute by the $\mathrm{j}^{\text {th }}$ respondent in State

$\mathrm{N}_{\mathrm{j}}=$ number of attributes

\section{Results}

\section{Socio-economic characteristics}

The socio economic characteristics of the migrant labours are shown in the Table 1 . The study indicated that 57 percent of respondents belong to the age group below 30 years. Followed by 28 percent of respondents are in the age group of more than 40 and 15 percent of the respondents are having the age between $30-40$.

The educational status indicated that, 52 per cent of respondents possesses high school level followed by 28 per cent of respondents completed secondary level of education and 10 percentages are completed higher secondary level. In the case of average monthly income 67 percentage of respondents have the income rage Rs.20, 000-30, 000 followed by 23 percentage of respondents having the income less than Rs. 20, 000 and only 10 percent having more than Rs. 30,000 income.

Table 1: Socio-economic characteristics

\begin{tabular}{|c|c|c|}
\hline $\begin{array}{c}\text { Socio economic } \\
\text { characteristics }\end{array}$ & Category & $\begin{array}{c}\text { Number of } \\
\text { respondents }\end{array}$ \\
\hline \multirow{3}{*}{ Age ( Years) } & Below30 & $57(57.00)$ \\
\cline { 2 - 3 } & $30-40$ & $15(15.00)$ \\
\cline { 2 - 3 } & More than 40 & $28(28.00)$ \\
\hline \multicolumn{3}{|c|}{} \\
\hline \multirow{4}{*}{ Education } & Primary & $8(8.00)$ \\
\cline { 2 - 3 } & High school & $52(52.00)$ \\
\cline { 2 - 3 } & Secondary & $28(28.00)$ \\
\cline { 2 - 3 } & $\begin{array}{c}\text { Higher } \\
\text { Secondary }\end{array}$ & $10(10.00)$ \\
\cline { 2 - 3 } & Graduate & $2(2.00)$ \\
\hline \multirow{4}{*}{ Income (Rs) } & Less than & $23(23.00)$ \\
\hline & 20,000 & $67(67.00)$ \\
\cline { 2 - 3 } & $20000-30,000$ & $10(10.00)$ \\
\cline { 2 - 3 } & $\begin{array}{c}\text { Greater than } \\
30,000\end{array}$ \\
\hline
\end{tabular}

Figures in parenthesis indicate percentage to total

While analyzing the religious orientation of the migrants labor it was found that 36 per cent belong to Muslim community who for better employment opportunities migrated from Jharkhand followed by Assam. 34 percent of the migrant were Hindus who migrated from Orissa and from other places of Karnataka and 30 percent of the people are Christians and are from Jharkhand. Figure 2 shows the religious orientation of the migrants.

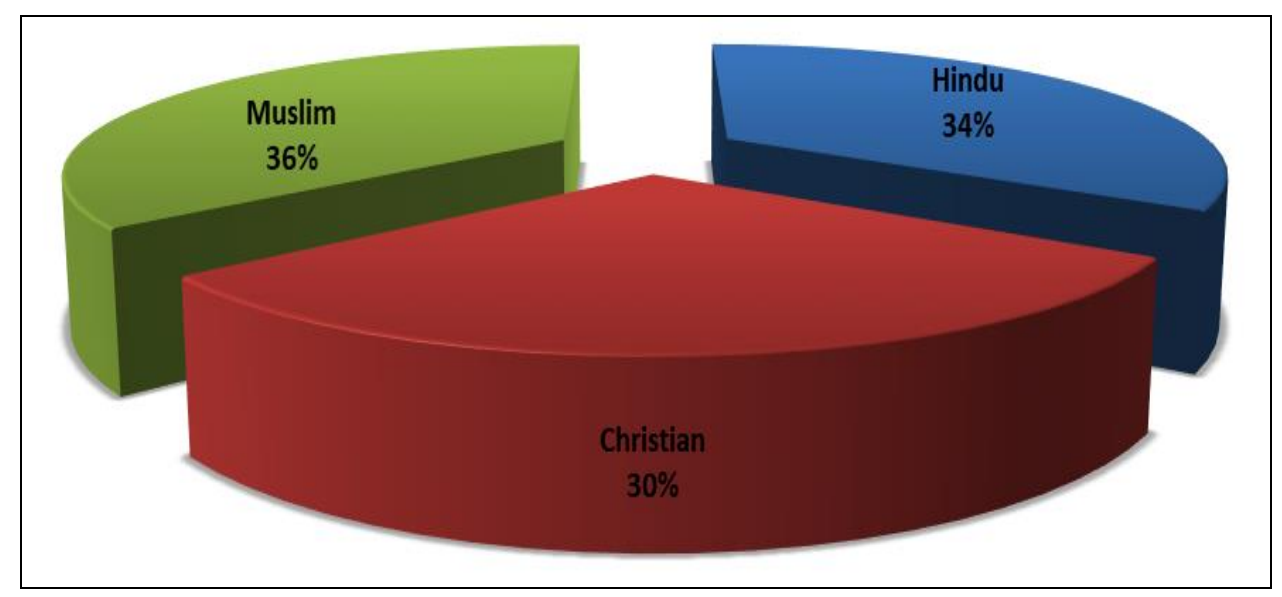

Fig 2: Religion of the migrants

\section{Pattern of expenditure}

The average monthly expenditure of the migrant laboureres respondents in Karnataka prior to and post migration was analyzed and it is furnished in Table 2. It indicated the average monthly expenditure on food is Rs.3020 (40.70 percent) which ranges from 4000 to a minimum of 2000 The expenditure on shelter followed next (26.95 percent). The average monthly expenditure on Health care (10.78 per cent) and social expense (8.09 per cent). The average monthly expenditure on clothes and Fuel/ electricity was found to be (6.74 percent).

It was found that consequent to migration the expenditure on food increased (2.01 percent). Expenditures like Shelter and Social expenses increased by 9.31 per cent and 0.63 per cent respectively. Other expenditures like Clothes, Fuel/
Electricity, and Health care decreased by 2.08 per cent, 3.01 per cent and 5.60 per cent.

Table 2: Expenditure pattern

\begin{tabular}{|c|c|c|}
\hline \multicolumn{2}{|c|}{$\begin{array}{c}\text { Average monthly } \\
\text { Pattern of expenditure (in /Month) }\end{array}$} \\
\hline Items & Home & Work place \\
\hline Food & $3020(40.70)$ & $4123(42.71)$ \\
\hline Clothes & $500(6.74)$ & $450(4.66)$ \\
\hline Shelter & $2000(26.95)$ & $3500(36.26)$ \\
\hline Fuel/Electricity & $500(6.74)$ & $360(3.73)$ \\
\hline Health care & $800(10.78)$ & $500(5.18)$ \\
\hline Social expenses & $600(8.09)$ & $720(7.46)$ \\
\hline Total & $7420(100)$ & $9653(100)$ \\
\hline
\end{tabular}

Figures in parenthesis indicate percentage to total 


\section{Details of migration}

Migration usually results due to various factors which are very difficult to predict. However socio-political, economic, environmental and ecological factors are considered to be the major forces driving migration. The fisher folks are influenced by these type of causative factors which provoke them to migrate. The period of migration and quantum of migration indicates the depth of migration. The details of migration of Mangalore district of Karnataka indicates that about 56 percent of the respondents included in the study migrated with their families and 44 percent of them migrated without their families to other places. Moreover the study point out that the migration took place in 5 different years. The highest quantum of migration was during 2000 (54 per cent) followedby 2004 (14 per cent), 2009 (12percent), 2002 and 2015 (10 percent) respectively. The study identified that the flow of migration shows a decreasing trend over the time period from 2000-2015.The year wise percentage of migration is clearly depicted in Figure 3.

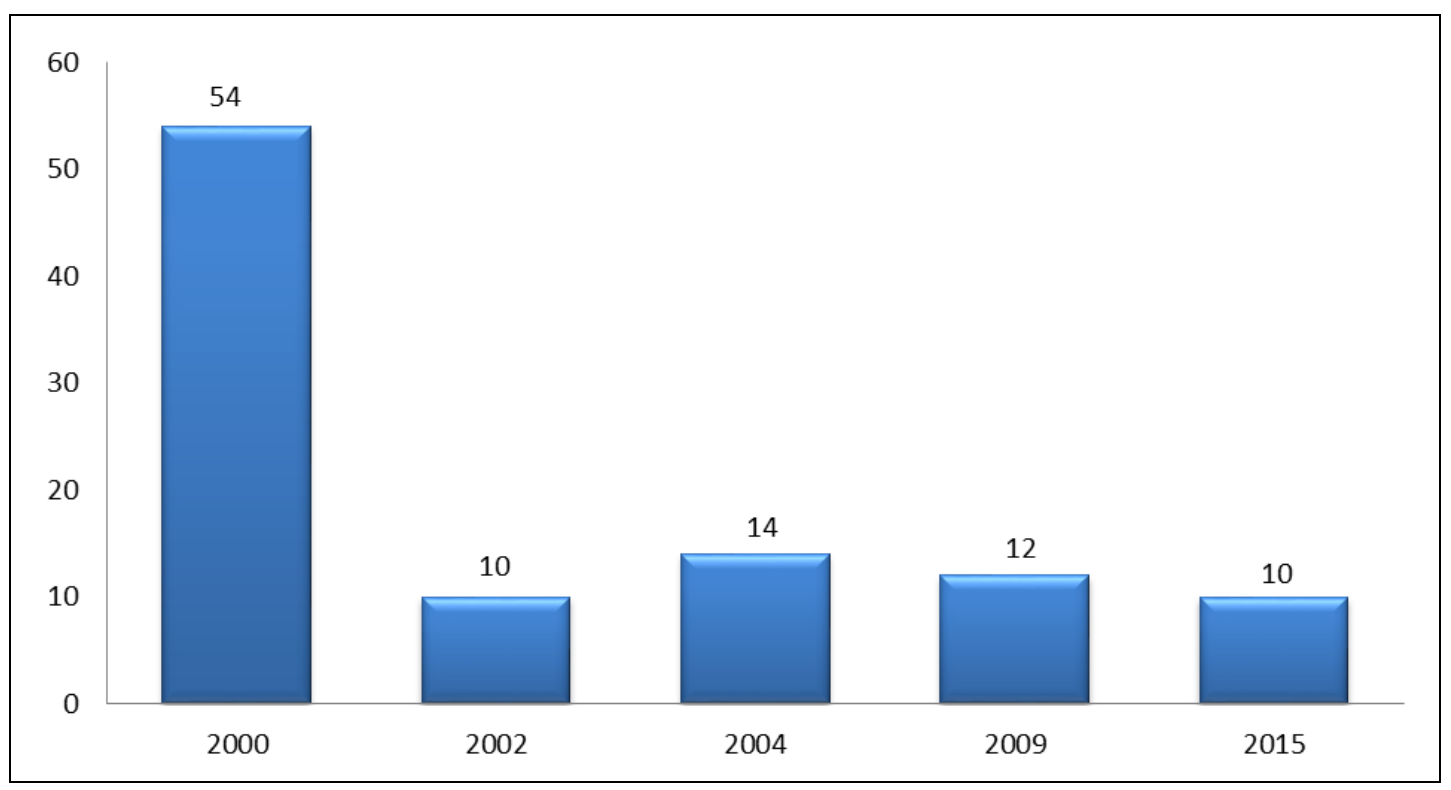

Fig 3: Year of migration

The migration details the respondents were indicated in figure 4 and the results shows that the respondents have migrated from five different states. Thirty six percent of people are from Jharkhand followed by 23 percent from Assam, 16 percent from other places of Karnataka, 13 percent Orissa and 12 percent from Kerala.

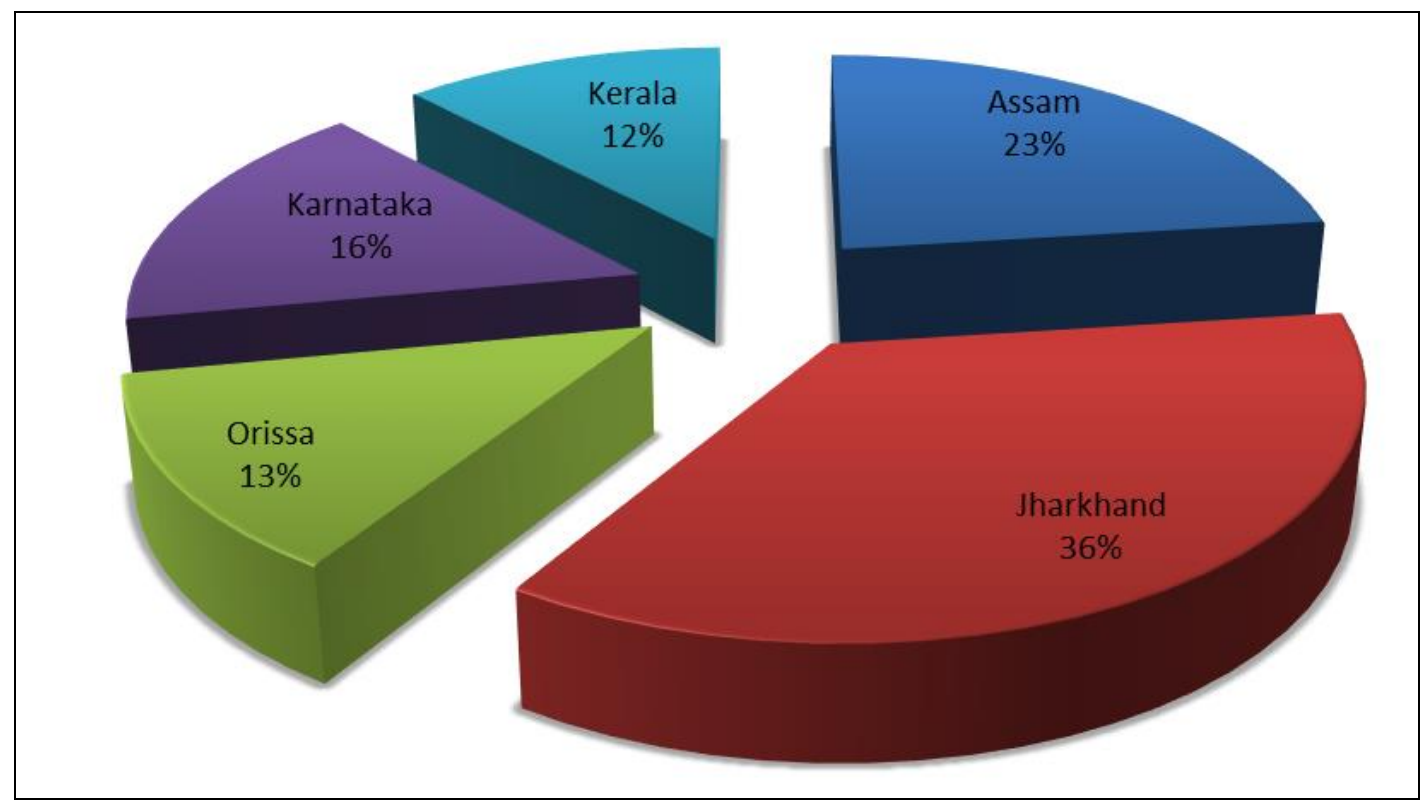

Fig 4: Profile of migrants

\section{Reason analysis}

The reason analysis was done on the basis of the opinion of the respondents. The Garrett ranking method is used to find the main parameter that leads to the migration. Most of the respondent opined the main reason for migration is low income followed by low level of education. (Table 3) 
Table 3: Reason for migration

\begin{tabular}{|c|c|c|}
\hline Parameters & Score & Rank \\
\hline Low Income & 93 & I \\
\hline Seasonality of employment & 84 & IV \\
\hline Debts \& Financial commitments & 86 & III \\
\hline Lack of technical knowledge & 82 & V \\
\hline Interest towards travelling & 80 & VI \\
\hline Low level of education & 88 & II \\
\hline Disguised employment at distant locations & 79 & VII \\
\hline Persuasion by friends & 77 & VIII \\
\hline
\end{tabular}

\section{Problem analysis}

Table 4: Problems during migration

\begin{tabular}{|c|c|c|}
\hline Parameters & Score & Rank \\
\hline Difficulty in Language & 93 & I \\
\hline Cultural Lag & 82 & V \\
\hline Lack of Education & 88 & II \\
\hline Competition amongst migrants & 86 & III \\
\hline Competition amongst locals & 79 & VII \\
\hline Lack of experience & 80 & VI \\
\hline Discrimination in terms of revenue sharing & 77 & VIII \\
\hline Inadequate skills other than fishing & 84 & IV \\
\hline
\end{tabular}

Major details regarding the problems and constraints faced by the migrants at the work place were also collected and analyzed in the study. The results obtained through Garrett ranking techniques are represented in Table 4, from which a clear picture of the problems can be retrieved.

The major problem faced by the migrants is the barriers of language as they moved from Northern and North Eastern India. In addition lack of education is the other problem faced by the migrants followed by lack of education, competition amongst migrants and amongst locals, lack of experience, discrimination in terms of revenue sharing and inadequate skills other than fishing.

The migrant labour visited their natives annually once and spend around one to two months spending their savings creating assets and attending social functions

The details regarding the remittances by the migrants to their home was analyzed and depicted in Fig. 5 which reveals that about 80 percent of the workers remit an average amount of Rs 5000 monthly. About 10 percent of the migrants are sending Rs.8,000 and Rs. 10,000, monthly. This indicates that the migrant remittances contributes to the welfare of the fishers family in their native place.

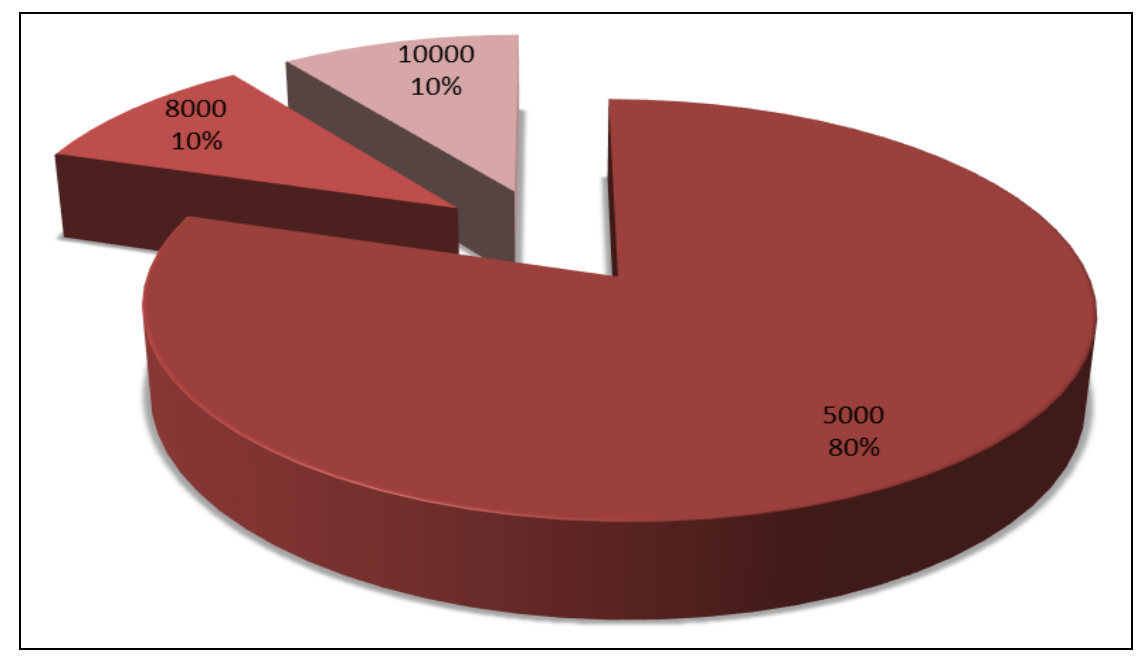

Fig 5: Monthly Remittances by the migrants to home

\section{Employment during closed season / Alternative avocations}

In Karnataka, the main off season for the migrant workers is the trawl ban period. There is a 60 days of trawl ban during the month of June and July. Most of the migrants were unemployed in this season. Majority of the workers choose alternate works during this season. The alternate avocation during ban period is shown in the Table 5 .

Table 5: Alternate avocation during ban period

\begin{tabular}{|c|c|}
\hline Job & Frequency \\
\hline Helper (Carpenter/Mason/Painting/Plumbing) & $15(15.00)$ \\
\hline Boat repair & $35(35.00)$ \\
\hline Agricultural labourer & $50(50.00)$ \\
\hline
\end{tabular}

Figures in parenthesis indicate percentage to total

According to the study majority of the people choose agriculture labourer as an alternate work during ban season. Fifty percent migrants choose agriculture labourers, 35 percentage migrants do boat repair works and 15 percent choose helping works like carpenter, mason, painting and plumbing.

\section{Effect of migration on socioeconomic status}

Based on the study conducted the major achievement of migration is the quality education. They are able to provide the quality education to their children. Secondly the respondent's savings increased due to the migration and due to the increase in the savings the respondents repaid the debts. Table 6 indicates the effect of migration on socio economic status of migrant labourers in Karnataka state. This indicates that the social economic status of the respondents improved due to the migration. This is because of the increased savings.

Table 6: Effect of migration in socioeconomic status

\begin{tabular}{|c|c|c|}
\hline Parameters & Score & Rank \\
\hline Constructed/Improved house & 82 & V \\
\hline Provided quality education & 93 & I \\
\hline Increased savings & 88 & II \\
\hline Debts were repaid & 86 & III \\
\hline Possessed assets & 79 & VII \\
\hline Improved social status & 80 & VI \\
\hline Marriage of dependents & 84 & IV \\
\hline
\end{tabular}




\section{Discussion}

The study identified that the majority of them migrated with their families and identified that low income and education levels constituted the main reasons for migration. The expenditure pattern of the migrants at their workplace as well as their home were analysed and the results indicates that when comparing the expenditure before and after migration the expenditure on food shows slight decrease after migration. The improvement in the social status, possessed assets and the quality of education provided to their children were the major achievements of migration of fishermen whereas difficulty in the language and competition amongst the fellow migrants were the major constraints during migration. The study revealed that regardless of their nativity, the workers are earning and saving much better through migration and are leading a peaceful life with minimal financial liabilities ${ }^{[18]}$. Hence it needs to provide proper policy measures to protect the rights of the migrants working in both the boat and the harbor. Proper training programs over the newly evolving fishing methods also have to be provided to build up the capacity of the workers ${ }^{[19]}$. Even though the migrants are experiencing many problems, the benefit that they enjoy outweighs most of the costs.

\section{Conclusion and Recommendation}

The social status of the respondents increased after migration. Savings give strength to the households. The average annual savings are increased due to migration. Most of the migrants have brought their own property which increased their social status. It can be concluded that young generations has a drive for seeking better opportunity for a better livelihood. Need for better housing facilities, health checkup etc on the migrant state for the laborers is important.

\section{Reference}

1. Viswanatha BS, Senthiladeban R, Rajakumar M, AmaliInfantina J. An overview of marine fisheries infrastructure and fish utilization pattern in Karnataka, India IJFAS 2015;2(4): 233-238

2. Bauman Z. Globalization: The human consequences Cambridge: Polity Press 126

3. Belton B, Marschke M, Vandergeest P. Fisheries development, labour and working conditions on Myanmar's marine resource frontier. Journal of Rural Studies 2019;69:204-213.

4. Islam MM, Herbeck J. Migration and translocal livelihoods of coastal small-scale fishers in Bangladesh. The Journal of Development Studies 2013;49(6):832-845.

5. Shyam, Salim S, Rahman M, Ramees, Athira NR. Labour migration and alternate avocation in marine fisheries sector of Kerala. Journal of the Marine Biological Association of India 2017;59(2):109-114.

6. Odotei I. Migration of Fante fishermen. FAO/Danida/Norway 1990, 168.

7. Percot, M. Bangladeshi Fishermen in Oman: Migration as a Gamble. In Asianization of Migrant Workers in the Gulf Countries Springer, Singapore 2020, 177-187

8. Lekshmi Swathi PS, Dineshbabu AP, Mahadevaswamy HS, Lingappa. Migrant labourers in the marine fisheries sector. Marine Fisheries Information Service T\&E 2011;207:26-27.

9. Swathi Lekshmi PS. Inter-Sectoral Mobility: The Case of Migrant Labourers in the Secondary Sector of Marine
Fisheries of Karnataka. International Journal of Extension Education 2017;13:11-16.

10. Kothari U. Migration and Chronic Poverty', Working Paper 16, Manchester: Chronic 2002

11. Sathiadhas R, Prathap K. Sangeetha Employment Scenario and Labour Migration in Marine Fisheries. Asian Fisheries Science 2009;22(2):713-727.

12. Sarma SB, Salagrama VENKATESH. Migration of Fishermen from Srikakulam District in Andhra Pradesh. Report of South Indian Federation of Fishermen's Societies 2007.

13. Nelson JM. 'Sojourners versus New Urbanites: Causes and Consequences of Temporary versus Permanent City ward Migration in Developing Countries', Economic Development and Cultural Change 1976;24(4):721-57.

14. Pradeep MD. Study on the Work Culture \& Socioeconomic Conditions of the Fishing Community working as Unorganised Labourers in Coastal Mangaluru, Karnataka.

15. Fregene, Bernadette Tosan. "Profile of Fishermen Migration in Nigeria and Implications for a Sustainable Livelihood." Department of Wildlife and Fisheries Management, University of Ibadan, Nigeria 2007, 20

16. De Haan A. 'Livelihoods and Poverty: the role of migration. A Critical Review of the Migration Literature', Journal of Development Studies 1999, 36.

17. De Haan A. 'Migrants, Livelihoods and Rights: the relevance of migration in development policies', Social Development Working London: DFID 2000; Paper no.4,

18. Dung, N. T. K., \&Loi, C. C. Economic costs and benefits of labour migration. Costs and Benefits of Cross-country Labour Migration in the GMS, 2012;2:305.

19. Keshri, Kunal, Ram B Bhagat. "Socioeconomic determinants of temporary labour migration in India: A regional analysis." Asian Population Studies 2013;9(2):175-195. 